\title{
水面上単分子膜の凝集構造の新しい分類 梶山千里・大石祐司
}

\author{
九州大学工学部応用物質化学教室 齿 812 福岡市東区箱崎 6-10-1
}

\section{Novel classification of aggregation structure of monolayers on the water surface}

\author{
Tisato Kajiyama, Yushi Oishi
}

\begin{abstract}
The melting temperature $\left(\mathrm{T}_{m}\right)$ and the crystalline relaxation temperature $\left(\mathrm{T} \alpha_{c}\right)$ of monolayers on the water surface were evaluated by a combination of two kinds of measurements, the subphase temperature $\left(\mathrm{T}_{s p}\right)$ dependence of monolayer modulus based on the $\pi-\mathrm{A}$ isotherm and also, the $\mathrm{T}_{s p}$ dependence of the electron diffraction (ED) patterns of monolayer. $\mathrm{T}_{m}$ and $\mathrm{T} \alpha_{c}$ of monolayers on the water surface are important to decide the phase structure or molecular aggregation state in the monolayers and also, formation of a large-area defect-diminished monolayer. Monolayer prepared from fatty acid molecules with nonionic hydrophilic groups is classified into a crystalline monolayer and an amorphous one in the case of $\mathrm{T}_{s p}$ below and above $\mathrm{T}_{m}$ of the monolayer on the water surface, respectively. Formation of the crystalline or amorphous monolayers is independent of the magnitude of surface pressure. The $\pi$-A isotherm for fatty acid monolayer represents the aggregating process of isolated domains grown right after spreading a solution on the water surface. The crystalline monolayer is further classified into the two types ; crystalline domains are assembled, resulting in aligning along their crystallographic axes due to an induced sintering at interfacial region among monolayer domains by surface compression at $\mathrm{T}_{s p}$ below $\mathrm{T} \alpha_{c}$ and also, domains are gathered without any special orientation among domains above $\mathrm{T} \alpha_{c}$. Monolayer prepared from amphiphilic molecules with ionic hydrophilic groups is classified into a compressing-crystallized monolayer (pressure-induced crystallization) and an amorphous one at $\mathrm{T}_{s p}$ below and above $\mathrm{T}_{m}$, respectively. In a region of very low surface pressure, even though $\mathrm{T}_{s p}$ is below $\mathrm{T}_{m}$, spontaneous crystallization is suppressed from strong repulsion among hydrophilic groups. This indicates that a pressure-induced crystallization is induced by compressing the amphiphilic molecules on the water surface.
\end{abstract}

Key words : monolayer, aggregation structure, fatty acid, anionic amphiphile, melting temperature, crystalline relaxation temperature, two-dimensional modulus, transmission electron microscopy, Fourier transform infrared spectroscopy

\section{1.はじめに}

分子レベルで構造制御が可能な単分子膜（ラングミュ
ア (L) 膜) やラングミュア・ブロジェット (LB) 膜は, 光集積回路, フォトクロミック素子, 光電変換素子等の 機能性有機超薄膜としての応用が期待され, その開発研 


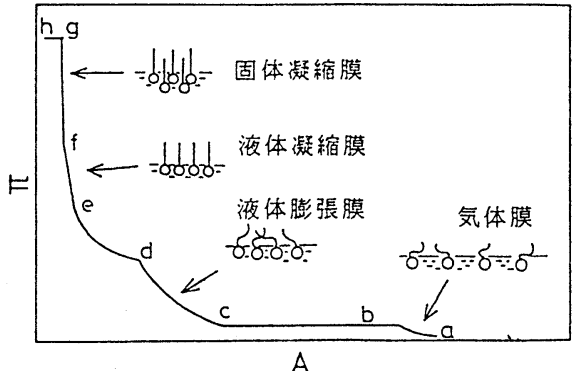

図 1 従来の単分子膜の構造モデル

究が進展している ${ }^{1} . \mathrm{LB}$ 膜に極限機能性を発現させる ためには低欠陥あるいは無欠陥 LB 膜の構築が不可欠で あり，この要請から LB 膜の構成単位である単分子膜の 凝集構造および低欠陥あるいは無欠陥単分子膜の構築法 に関心が寄せられるようになってきた。 親水部と疎水部 を化学的に結合した両親媒性分子が，分子内における表 面自由エネルギーの大きく異なる親・疎水部のため，水 一空気界面で単分子膜を形成することが Pockels ${ }^{22}$, Rayleigh $^{3)}$, Langmuir ${ }^{4)}$ らにより明らかにされた. それ以来, 単分子膜の構造はその圧縮過程で得られる等 温曲線に基づいてのみ議論され，次節で示す単分子膜の 構造概念が広く受け入れられていた。 近年, 単分子膜と いう極限超薄層における分子集合体の構造評価が可能な 透過型電子顕微鏡, 全反射 X 線回折法, FT-IR 分光法, ラマン散乱法, 蛍光顕微鏡, 原子間力顕微鏡等の様々な 手法が開発され，これらの手法による形態構造論的検討 から水面上単分子膜の凝集構造の実像が明らかになりつ つある. 本報では, 透過型電子顕微鏡, FT-IR 分光法 を用いた著者らの最近の研究結果をまとめ, 単分子膜の 凝集構造の新しい概念之低欠陥単分子膜の構築法につい て解説する。

\section{2. 従来の水面上単分子膜形成の概念}

図 1 は, 水面上の両親媒性分子をバリヤーで圧縮する 過程で得られる表面圧一表面積 $(\pi-A)$ 曲線之各表面 圧でのそれら分子凝集状態の模式図である. 三次元気体 の凝集過程で得られる圧力一体積曲線に基づき，二次元 の水面上における両親媒性分子は低圧・大面積下で気体 膜 $(a-b)$ となり，圧縮にともない気液共存膜 $(b-c)$, 液 体膨脹膜 $(c-d)$, 中間膜 $(d-e)$, 液体凝縮膜 $(e-f)$, 固体 凝縮膜 (f-g) という凝集状態をとると考えられていた ${ }^{5)}$. しかし, 水面上での単分子膜形成過程は必ずしも熱力学

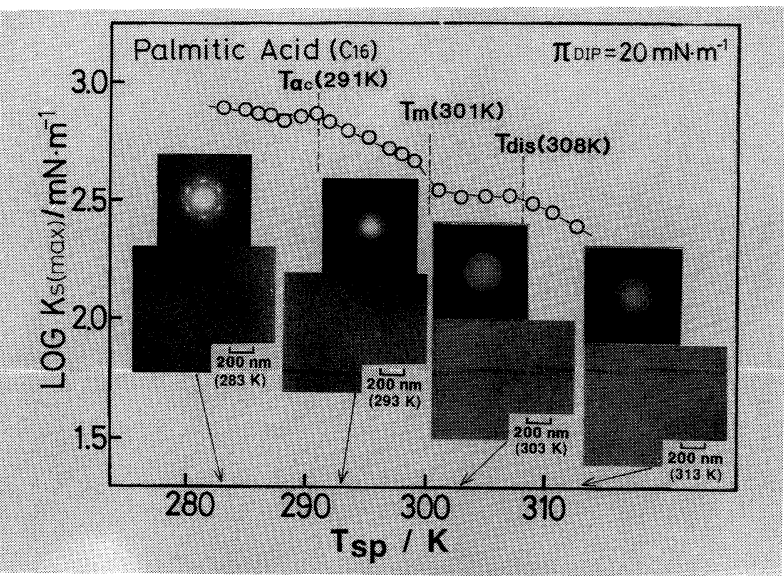

図 2 パルミチン酸単分子膜の $\log \mathrm{K}_{S_{(\text {max })}}$ の水相 温度依存性亡 $20 \mathrm{mN} \mathrm{m}^{-1}$ での単分子膜の電 子線回折像

的に閉じた系ではなく, 気体の凝縮過程での閉じた系と 同様な議論が可能であるのか，また，通常固体膜と呼ば れる単分子膜の表面圧は数 $10 \mathrm{mN} \mathrm{m}^{-1}$ であり，この様 な非常に低い圧力のみで非晶相から結晶相への転移が可 能であるのか，という疑問点は充分議論されていない。

\section{3. 単分子膜の熱的挙動}

水面上単分子膜の凝集状態は表面圧のみならず，両親 媒性分子の化学構造, サブフェーズ (水相) の状態, 溶 媒種に強く依存するが，特に単分子膜の分子熱運動状態 が決定的影響を与える. 私共が単分子膜研究を始めた, 今から 5 年前には水面上単分子膜の熱力学的因子の解明 が十分でないことには驚かされた，そこで，水面上単分 子膜の融点と結晶緩和温度の評価を試みた。

単分子膜の面積弾性率 $\left(\mathrm{K}_{s}\right)$ は，表面圧 $(\pi)$-表面積 (A) 曲線に基づき次式により算出できる ${ }^{6}$.

$$
\mathrm{K}_{s}=-\mathrm{A}(\mathrm{d} \pi / \mathrm{d} \mathrm{A})
$$

$\mathrm{K}$ 。は，単分子膜内の分子鎖のパッキングが最も緻密に なったときに最大值 $\left(\mathrm{K}_{s(\max )}\right)$ をとる.このときに圧縮 力は単分子膜に均一に伝播すると考えられ， $\mathrm{K}_{s(\max )}$ を 単分子膜の凝集状態を表す指標とした.

図 2 は, 純水上に展開したパルミチン酸単分子膜の $\log \mathrm{K}_{s(m a x)}$ の水相温度 $\left(\mathrm{T}_{s p}\right)$ 依存性および表面圧 20 $\mathrm{mN} \mathrm{m}^{-1}$ で親水性基板上に移しとった単分子膜の電子 線回折 $(E D)$ 像である. 単分子膜の形態学的および構 造論的研究には, 水面上の単分子膜の結晶構造を保持し 


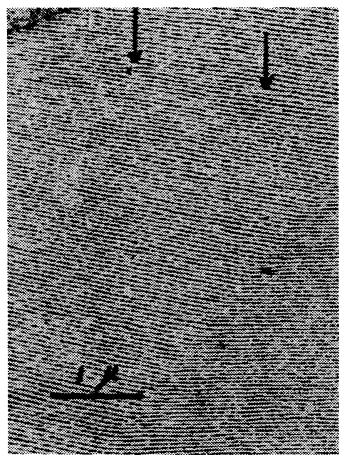

Grown at $70^{\circ} \mathrm{C}$

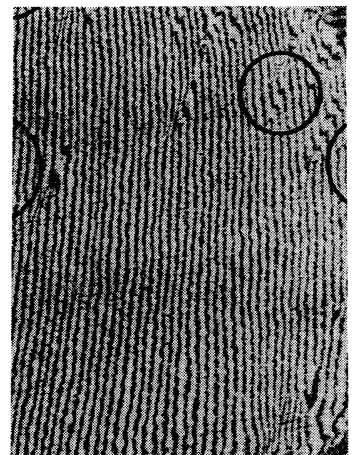

Annealed at $75^{\circ} \mathrm{C}$

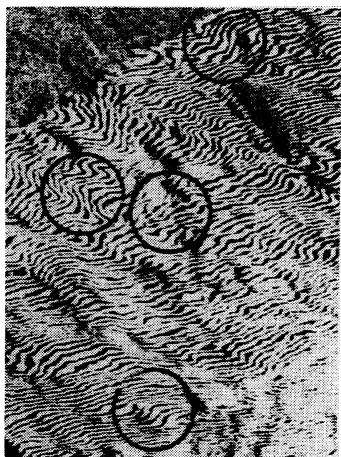

Annealed at $85^{\circ} \mathrm{C}$

図 3 ポリエチレン単結晶の (110) 回折によるモアレ図形

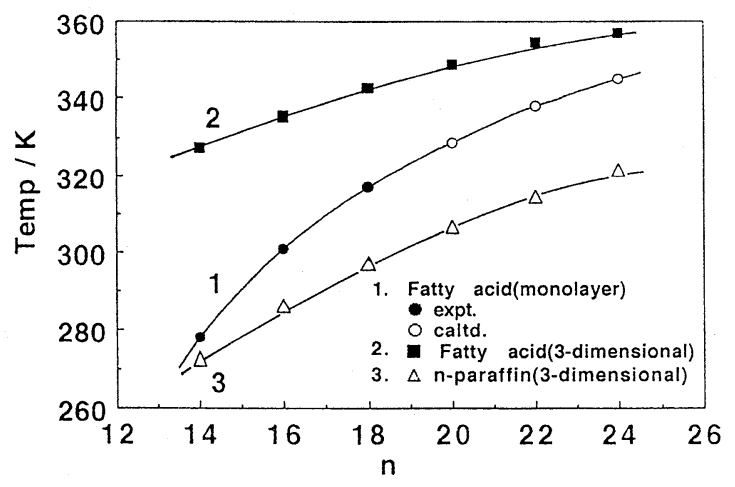

図.4融点のアルキル鎖長依存性

たまま移しとることが可能な親水性の $\mathrm{SiO}$ 基板を用 $\left(^{6)}, \mathrm{ED}\right.$ 像の撮影は単分子膜調製時の水相温度と同じ 温度で行った. $\log \mathrm{K}_{s(m a x)}$ 対 $\mathrm{T}_{s p}$ の傾きは $\mathrm{T}_{s p}=291$, 301 および $308 \mathrm{~K}$ 近傍で顕著に変化した.

$291 \mathrm{~K}$ 以下の低温域では ED 像が鋭い結晶性の 6 点 スポットを示したのに対し, 高温域では結晶性のデバイ リングになり，291 K より高温域では結晶軸の方位が乱 れることが明らかとなった。 また，ED像から評価した 単分子膜の二次元結晶の (10) の面間隔の熱膨脹係数が

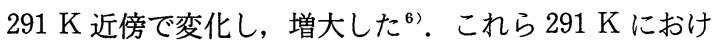
るパルミチン酸単分子膜の $\log K_{s(m a x)}$ の低下および 熱膨脹係数の増大は, 結晶性高分子の単結晶マットや球 晶を形成する溶融結晶化物あるいは合成ポリペプチドで 詳細に研究された力学的結晶緩和挙動のそれと類似して (る ${ }^{7 \sim 13)}$. 結晶緩和とは結晶相内の分子鎖の熱運動性 が活発となり分子間ポテンシャルの非調和項が増加する ため結晶が粘弾的となる現象であり，動的損失弾性率の 極大温度の結晶厚依存性 ${ }^{7)}$, 結晶の熱膨脹係数 ${ }^{10)}$ や音

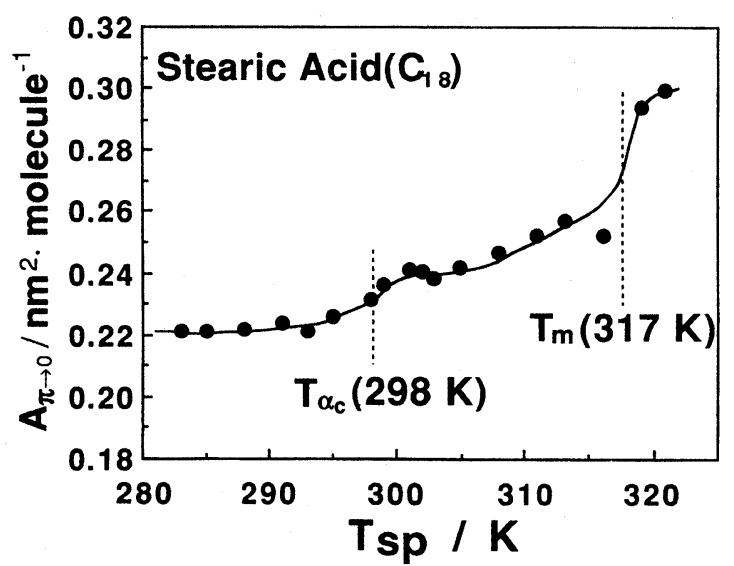

図 5 ステアリン酸単分子膜の極限面積の水相温度 依存性

速の圧力依存性と圧縮率より評価される Grüneisen 定 数の温度依存性 ${ }^{11}$ 少らその機構が明らかとなっている. 結晶相の融点よりはるかに低い結晶緩和温度域でも図 3 に示すように結晶相内で著しい構造変化が生じている. 図3 は, $70^{\circ} \mathrm{C}$ で等温結晶化した $\mathrm{PE}$ 単結晶の電子顕微鏡 暗視野像（モアレ像）である. 結晶格子中の分子鎖配列 に高度な規則性がある単結晶の結晶方位が僅かにずれて 重なっている場合には, 単結晶の暗視野像には, ずれの 角度に依存してモアレ図形或いは転位網が観察される. この単結晶を高密度ポリエチレンの $\mathrm{T}_{m}=140^{\circ} \mathrm{C}$ よりは るかに低い結晶緩和温度域の 75 と $85^{\circ} \mathrm{C} て ゙$ 熱処理した 暗視野像は, 結晶相中の分子鎖間隔あるいは結晶方位の 不整のため転位網が乱れ, 格子欠陥 (刃状転位) の増殖 （図中○で囲まれている）が著しくなっていることを示 している ${ }^{12)}$. また, X 線回折強度の温度依存性より, 


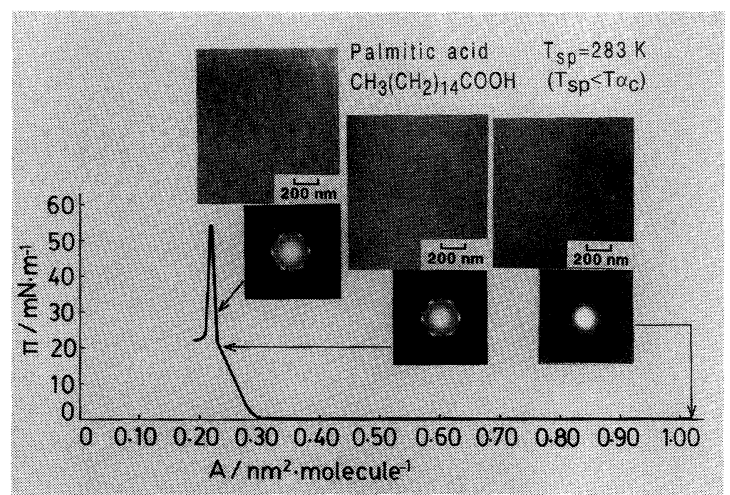

(a)

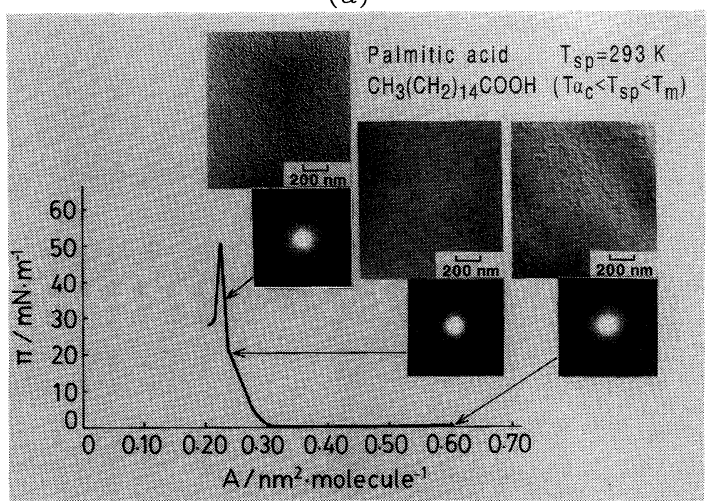

(b)

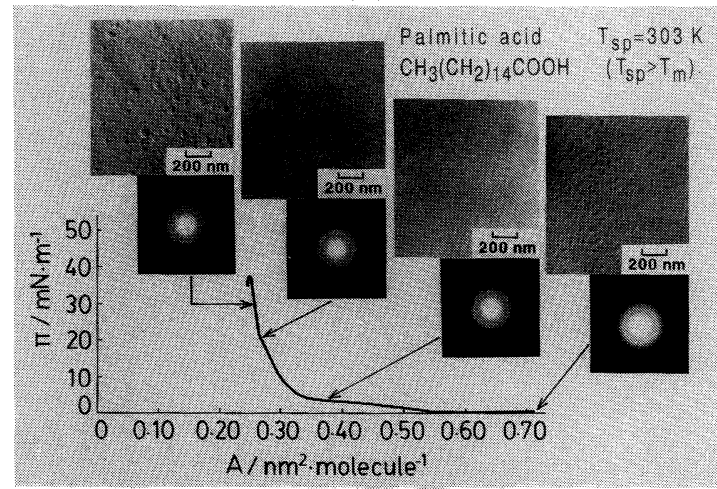

(c)

図 6 パルミチン酸単分子膜の $\pi-\mathrm{A}$ 曲線と各表面 圧での明視野像之電子線回折像

(a) $283 \mathrm{~K}\left(\mathrm{~T}_{s p}<\mathrm{T} \alpha_{c}\right)$, (b) $293 \mathrm{~K}\left(\mathrm{~T} \alpha_{c}\right.$ $\left.<\mathrm{T}_{s p}<\mathrm{T}_{m}\right)$, (c) $303 \mathrm{~K}\left(\mathrm{~T}_{s p}>\mathrm{T}_{m}\right)$

結晶緩和温度域において分子軸周りの回転や振動により 結晶不整を含む結晶格子が増加することが報告されてい $ろ^{13)}$. 以上の結果より, 高分子単結晶之同様に結晶性 単分子膜も粘弾的結晶緩和特性を示すと考えて良い.

図 2 のパルミチン酸の水面上単分子膜の $\mathrm{ED}$ 像が 293 $\mathrm{K}$ でデバィリング, $303 \mathrm{~K}$ でアモルファスハローとなる
ことより, $\log \mathrm{K}_{s(\text { max } x)}$ が急激に減少する $301 \mathrm{~K}$ は単 分子膜の融解に対応していると考えてよい（パルミチン 酸の三次元結晶の融点は $335.6 \mathrm{~K}$ である). 同様の方法 でアルキル鎖長の異なる脂肪酸単分子膜の融点 $\left(\mathrm{T}_{m}\right)$ と 結晶緩和温度 $\left(\mathrm{T} \alpha_{c}\right)$ を評価することができる.

図 4 は, 脂肪酸の単分子膜, 三次元結晶およびパラ フィンの三次元結晶の $\mathrm{T}_{m}$ のアルキル鎖長依存性であ る. パラフィンの $\mathrm{T}_{m}$ は Broadhurst の式 ${ }^{14)} よ り$ 算出 した。 上述した $\log \mathrm{K}_{s(m a x)}$ と $\mathrm{ED}$ 像の $\mathrm{T}_{s p}$ 依存性よ り評価したミリスチン酸 $\left(\mathrm{C}_{14}\right)$, パルミチン酸 $\left(\mathrm{C}_{16}\right)$, ステアリン酸 $\left(\mathrm{C}_{18}\right)$ 単分子膜の $\mathrm{T}_{m}$ は, 各々 $278 \mathrm{~K}$, $301 \mathrm{~K}, 317 \mathrm{~K}$ であった. これら $\mathrm{T}_{m}$ の実測值に基づき $\mathrm{T}_{m}$-アルキル鎖長依存性を補外することによりアラキジ ン酸 $\left(\mathrm{C}_{20}\right)$, ベヘン酸 $\left(\mathrm{C}_{22}\right)$, リグノセリン酸 $\left(\mathrm{C}_{24}\right)$ の $\mathrm{T}_{m}$ を予測し, 図 4 に加えた. 脂肪酸の $\mathrm{T}_{m}$ は, 単分子 膜の方が三次元結晶より低く，その差はアルキル鎖長の 増加とともに減少する。この事実は，アルキル鎖長と共 に分子間凝集力が増加し熱力学的により安定な単分子膜 が形成されることを示している6.15).

図 5 は, ステアリン酸単分子膜の極限面積の $\mathrm{T}_{s p}$ 依 存性である. 極限面積は, $\pi$-A 曲線を $\pi=0$ に補外す ることにより評価した，極限面積の $\mathrm{T}_{s p}$ 依存性は， $\mathrm{T}_{s p}$ $=298 \mathrm{~K}$ および $317 \mathrm{~K}$ 近傍で変化した。 これらの温度は $\log \mathrm{K}_{s(m a x)}$ と $\mathrm{ED}$ 像の $\mathrm{T}_{s p}$ 依存性より評価したステ アリン酸単分子膜の各々 $\mathrm{T} \alpha{ }_{c}$ と $\mathrm{T}_{m}$ とよい一致を示す ことより, $298 \mathrm{~K}$ および $317 \mathrm{~K}$ の極限面積の增加は, そ れぞれ結晶格子の熱膨脹係数の増加および固一液相転移 による分子占有面積の顕著な増加に対応している. 図 5 の結果は, 図 2 で示した $\log \mathrm{K}_{s(\text { max })}$ ¿ ED 像の $\mathrm{T}_{s p}$ 依存性に基づく水面上単分子膜の $\mathrm{T} \alpha_{c}$ と $\mathrm{T}_{m}$ の決定法 が正しいことを支持するものである ${ }^{6)}$. $\mathrm{T} \alpha_{c}$ と $\mathrm{T}_{m}$ は, 以下に示すように単分子膜の凝集構造の決定のみなら ず, 低欠陥あるいは無欠陥単分子膜の構築法の探索に重 要な因子となる.

\section{4. 単分子膜の凝集構造}

種々の表面圧で一定温度に保った水面上の単分子膜を その凝集状態を保ったまま累積することのできる $\mathrm{SiO}$ 基板上に移しとり，透過型電子顕微鏡 (TEM) 観察を 行った．明視野像観察の際には，単分子膜の外形之表面 状態を鮮明にするため, $23^{\circ}$ の角度をつけて白金 - カー ボンでシャドウイングをした. 


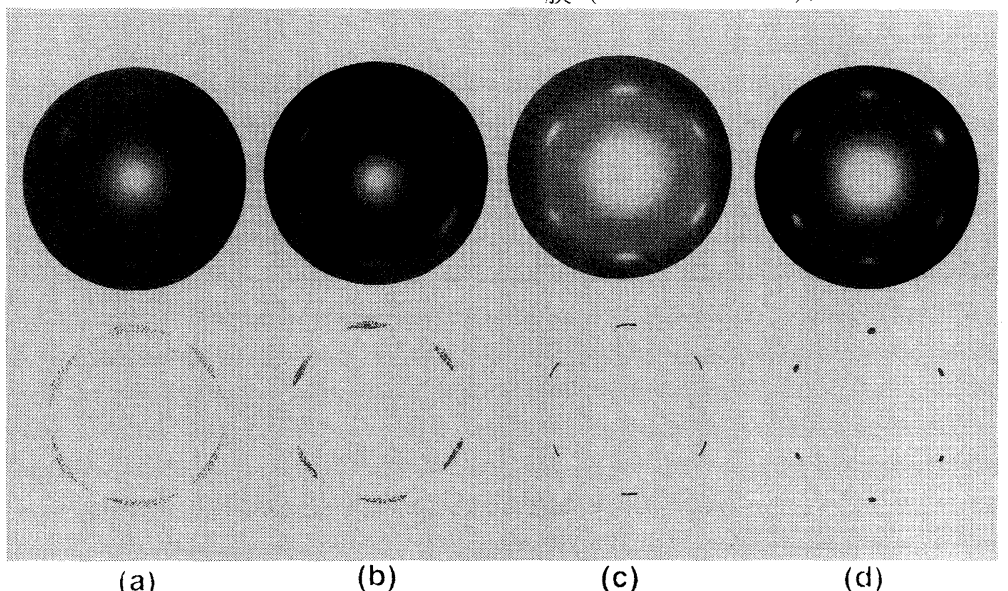

(a)

一定表面積保持によるベヘン酸単分子膜の電子線回折像変化
(a) 100 秒，(b) 1000 秒,
(c) 2000 秒, (d) 3000 秒

\section{1. 結晶性単分子膜亡非晶性単分子膜}

図 6 (a) は，パルミチン酸単分子膜の $\mathrm{T} \alpha$ 。以下の $\mathrm{T}_{s p}=283 \mathrm{~K}$ における $\pi$-A 曲線と各表面圧における TEM による明視野像および ED 像である. $\pi-\mathrm{A}$ 挙動 は，表面積の減少とともに表面圧が急激に增加する．表 面圧 $0 \mathrm{mN} \mathrm{m}^{-1}$ における明視野像ではコントラストの 明確な海島構造が観察され，さらに ED 像が結晶性の デバイリングを示すことから，水面上にパルミチン酸希 薄溶液を展開した直後から, すでに結晶方位のランダム な二次元結晶性ドメインが析出していることが明らかで ある．表面圧の増加にともない明視野像では，二次元結 晶性ドメインが凝集していく過程が観察され，ED 像は 6 点スポットへと変化した。これらの結果は, 試料溶液 展開時にすでに結晶性ドメインが形成され，圧縮操作は それらドメインを寄せ集める過程であることを示してお り，ポリジアセチレン単分子膜の偏光・蛍光顕微鏡観

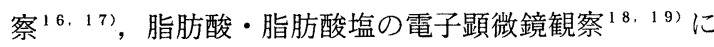
おいても同様の結論が得られている，さらに，圧縮によ るデバイリングから 6 点スポットへの $\mathrm{ED}$ 像の変化は, 圧縮により結晶性ドメイン間の融着が生じ, 大きな二次 元単結晶となったためと考えられる. 図 7 は, $\mathrm{T} \alpha$ ～以 下の $\mathrm{T}_{s p}=293 \mathrm{~K}$ で表面圧 $35 \mathrm{mN} \mathrm{m}^{-1}$ まで圧縮後, 100 3000 秒間一定表面積を保持したベヘン酸単分子膜 の ED 像である. 長時間保持するに従い, ED 像は方位 角方向に鋭い結晶性 6 点スポットになる．したがって， $\mathrm{T}_{s p}$ が $\mathrm{T} \alpha_{c}$ 以下でも高表面圧まで圧縮した直後では, 二次元結晶性ドメインの界面での融着結晶配向化は不完
全であるが，一定表面積で数千秒保持することにより融 着結晶配向化が十分に進行し，結晶方位が高度に揃った 大面積単分子膜が形成されることは明らかである ${ }^{20)}$. 融着結晶配向化は速度論的過程であるので, 単分子膜の 大面積化には圧縮速度といった圧縮の操作方法も考慮す る必要がある，これらの結果から，結晶緩和現象が結晶 性ドメイン界面における融着に多大な影響を与えている ことが明らかである ${ }^{6}$. 以上のように $\mathrm{T}_{s p}<\mathrm{T} \alpha$ 。 の場 合は，圧縮により結晶性ドメイン間の融着が起こる『圧 縮融着配向・結晶性単分子膜』となる.

図 6 (b) は, パルミチン酸単分子膜の $\mathrm{T} \alpha$ c 以上で $\mathrm{T}_{m}$ 以下である $293 \mathrm{~K}$ で水面展開した場合の $\pi$-A 曲線之 TEM 観察結果である. $\pi$-A 挙動および結晶性ドメイ ンが凝集する過程は図 6 (a) に示した $\mathrm{T} s$ s の場合とほとんど同様であるが，高表面圧においても $\mathrm{ED}$ 像は 6 点スポットとならず結晶性デバイリングのま まであった．以上のように $\mathrm{T}_{s p}$ が $\mathrm{T} \alpha_{c}$ 以上で $\mathrm{T}_{m}$ 以下 の場合には, 結晶性ドメインが凝集しても結晶方位が揃 わない『ランダム配向・結晶性単分子膜』となる.

図 6 (c) は，パルミチン酸単分子膜の $\mathrm{T}_{m}$ 以上である $303 \mathrm{~K}$ における $\pi$-A曲線と TEM 観察結果である. 図 6 (a), 図 6 (b) の結晶性単分子膜の場合とは異なり, $\pi-\mathrm{A}$ 曲線にはプラトー領域が観測された. 表面圧 $0 \mathrm{mN} \mathrm{m}^{-1}$ においては，コントラストの弱い海島構造が観察される が ED 像はアモルファス八ローであり, 溶液展開直後 には非晶状態の構造体が存在することが明らかである. 圧縮により非晶性ドメインが凝集する過程が観察される が ED 像はアモルファス八ローのままであり, 圧縮に 


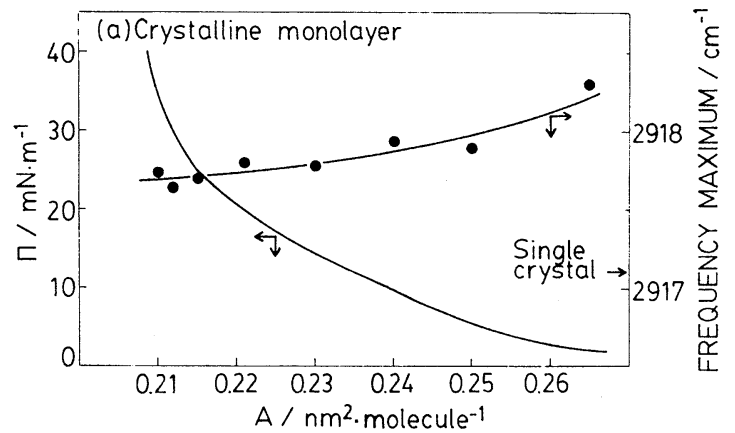

(a)

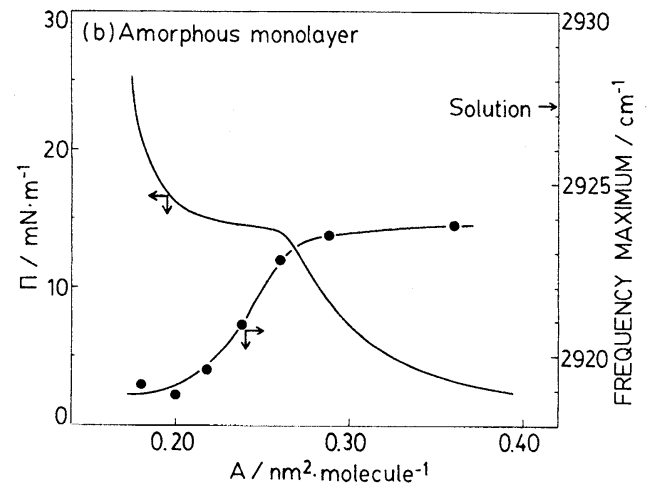

(b)

図 8 単分子膜の表面圧および $\mathrm{CH}_{2}$ 逆対称伸縮振 動の極大波数の表面積依存性

(a) ステアリン酸結晶性単分子膜

(b) ミリスチン酸非晶性単分子膜

よる非晶相から結晶相への相転移は観測されなかった。 以上のように $\mathrm{T}_{s p}$ が $\mathrm{T}_{m}$ 以上の場合は，溶液展開直後に 形成された非晶性ドメインが圧縮により凝集する『非晶 性単分子膜』となる.

結晶性および非晶性単分子膜の圧縮過程における分子 鎖凝集状態の变化，すなわち単分子膜の分子鎖のコンホ メーション変化を赤外分光法に基づき検討した。アルキ ル鎖のトランスコンホメーションの分率が増加するに従 い $\mathrm{CH}_{2}$ 対称および逆対称伸縮振動バンドの波数が低波 数側にシフトすることが報告されている ${ }^{21,22)} . \mathrm{T}_{s p}$ $=293 \mathrm{~K}$ の水面上で調製したステアリン酸結晶性単分子 膜 $\left(\mathrm{T}_{m}=317 \mathrm{~K}\right)$ およびミリスチン酸非晶性単分子膜 $\left(\mathrm{T}_{m}=278 \mathrm{~K}\right)$ を, 各表面圧で, 垂直引き上げ法により $\mathrm{CaF}_{2}$ 板に $\mathrm{SiO}$ を蒸着した基板上に移しとり, 透過法 による赤外吸収スペクトルを測定した。図 8 (a) は, ス テアリン酸結晶性単分子膜の $\pi-\mathrm{A}$ 曲線と各表面圧での $\mathrm{CH}_{2}$ 逆対称伸縮振動の極大波数である. $\mathrm{CH}_{2}$ 逆対称伸
縮振動の極大波数は表面圧にほとんど依存せず, 高表面 圧での $\mathrm{CH}_{2}$ 逆対称伸縮振動の極大波数は $2917.7 \mathrm{~cm}^{-1}$ であり，この值は $\mathrm{CH}_{2}$ 鎖の全てがトランスであるステ アリン酸単結晶の $2917.1 \mathrm{~cm}^{-1}$ の值に非常に近い值で あった.この結果は，ステアリン酸結晶性単分子膜中の アルキル鎖のコンホメーションが全トランス型に近いこ とを示している. 表面圧の增加にともなう $\mathrm{CH}_{2}$ 逆対称 伸縮振動の極大波数の変化は非常にわずかであり, 圧縮 過程で結晶性単分子膜中のアルキル鎖のコンホメーショ ンはほとんど变化しないと考えて良い.

図 8 (b) は, ミリスチン酸非晶性単分子膜の $\pi-\mathrm{A}$ 曲 線と各表面圧での $\mathrm{CH}_{2}$ の逆対称伸縮振動の極大波数で ある. 低表面压での極大波数は $2923.8 \mathrm{~cm}^{-1}$ であった. 四塩化炭素溶液中のミリスチン酸およびステアリン酸単 結晶の極大波数が各々 $2927.3 \mathrm{~cm}^{-1}$ と $2917.1 \mathrm{~cm}^{-1}$ で あることより，低表面圧での非晶性単分子膜中のアルキ ル鎖のコンホメーションは溶液中の脂肪酸分子のそれに 近く, ゴーシュコンホメーションの分率がかなり高いこ とを示唆している. 表面圧の増加にともない，特に $\pi-\mathrm{A}$ 曲線のプラトー領域で $\mathrm{CH}_{2}$ 逆対称伸縮振動の極大波数 が顕著に減少することから, プラトー領域での単分子膜 の圧縮により非晶性単分子膜中のアルキル鎖のトランス コンホメーション分率が増加し, 分子鎖の配向秩序化が 進行することが明らかである.これより， $\pi$-A 曲線上 でのプラトーの出現は, 分子鎖の秩序化に圧縮エネル ギーが消費される擬平衡状態と考えられる ${ }^{23)}$.

以上の結果より, 純水上での脂肪酸単分子膜は $\mathrm{T}_{m}$ 之 $\mathrm{T}_{s p}$ との関係から『結晶性単分子膜』と『非晶性単分子 膜』に大別できることが明らかとなった ${ }^{6.23)}$.

\section{2. 圧縮結晶化単分子膜}

前節 (4.1) で解説した脂肪酸は純水上で極性基のほ とんどがノニオン性であり, 単分子膜の相状態は水面上 単分子膜の $\mathrm{T}_{m}$ と $\mathrm{T}_{s p}$ との関係で決まる. しかし, 分 子間の反発力の強いイオン性極性基をもつ両親媒性分子 から構成される単分子膜の場合には, 前節で解説した結 晶性あるいは非晶性単分子膜とは異なる凝集構造を示 す.

図 9 は, 親水部がスルホン酸ナトリウムであるアニオ ン性両性物質の化学構造とその単分子膜の $\mathrm{T}_{m}=316 \mathrm{~K}$ 以下の $\mathrm{T}_{s p}=293 \mathrm{~K}$ での $\pi-\mathrm{A}$ 曲線と透過型電子顕微鏡 観察による明視野像と ED 像の表面圧依存性である. $\pi$-A 曲線には表面圧約 17 から $21 \mathrm{mN} \mathrm{m}^{-1}$ の範囲で 
$2 \mathrm{C}_{14} \mathrm{SNa}$ (Anionic Amphiphile)
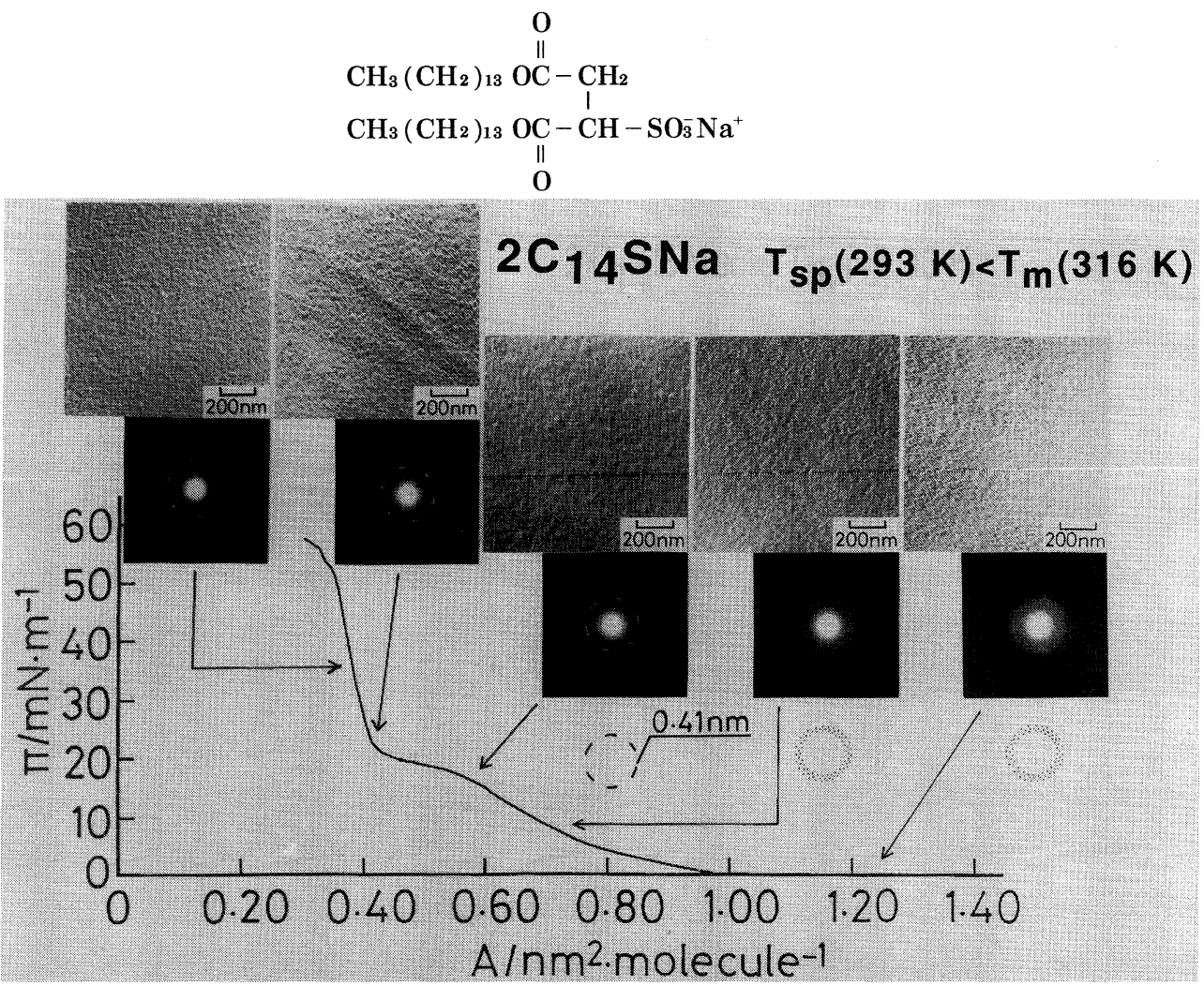

図 9 アニオン性人工両性物質の化学構造およびその $\pi$-A 曲線と各表面圧での明視野像と電子線回折像

プラトー領域が観測された。いずれの明視野像も均一で あり，低表面圧で明確なドメイン構造を示した脂肪酸単 分子膜の場合と対照的である。これは，極性基の静電的 反発力のために分子同士が凝集できずドメインを形成し ないと考えられる. ED 像は，プラトー以下の表面圧で はアモルファスハローであったが，プラトーとなる 17 $\mathrm{mN} \mathrm{m} \mathrm{m}^{-1}$ では方位角方向に幅広い結晶性の 6 点像と なった。これより圧縮により単分子膜が非晶状態から結 晶状態へ相転移したことは明らかである.アニオン性両 性分子の極性基間には強い静電的反発力が働くため, 分 子が結晶化する程互いに近づくためには高い表面圧を必 要とすることを示唆している ${ }^{24)}$. $\pi$-A 曲線のプラトー の表面圧より僅かに高い $21 \mathrm{mN} \mathrm{m}^{-1}$ から $35 \mathrm{mN} \mathrm{m}^{-1}$ の間では，ED 像は方位角方向により鋭く配向した 6 点 像となり，結晶性ドメインの結晶方位がさらによく揃っ て単分子膜が結晶学的に大面積化する過程が観察され た.これはプラトー以上の表面圧における圧縮操作によ り結晶性ドメインの界面が融着するためと考えられ
る ${ }^{6)}$. 他方, $\mathrm{T}_{m}$ よりわずかに低い $\mathrm{T}_{s p}=315 \mathrm{~K}$ では, 圧縮による非晶状態から結晶状態への相転移は観察され たが, 高表面圧でも結晶方位は揃わなかった. 前節 (4.1) で解説した脂肪酸分子の $\mathrm{T} \alpha$ 。のアルキル鎖長依存性か ら予測すると，ア二オン性両性分子単分子膜の $\mathrm{T} \alpha_{c}$ は 293 から $315 \mathrm{~K}$ の間に存在すると考えられ，アニオン性 両性分子単分子膜の場合にも脂肪酸単分子膜の場合之同 様に $\mathrm{T} \alpha_{c}$ 以上の $315 \mathrm{~K}$ では結晶性ドメイン間での融着 が生じないと考えられる. また, $\mathrm{T}_{m}$ 以上の $\mathrm{T}_{s p}=318 \mathrm{~K}$ の場合には ED 像は各表面圧ともアモルファスハロー であり，アニオン性両性分子は非晶性単分子膜を形成す ることが明らかとなっている．圧縮による単分子膜の非 晶から結晶への相転移は極性の強いリン酸基を親水部に 有するリン脂質単分子膜でも生じることが，電子線回折 法 $^{25)}$ およびシンクロトロン放射光を用いた水面上での 全反射法 ${ }^{26)}$ により確認されている. 以上より, 強い極 性基を有する両親媒性分子の場合には極性基同士に強い 静電的反発力が働き，表面圧が低く分子の占有面積が十 
表 1 . 単分子膜の凝集構造の分類表

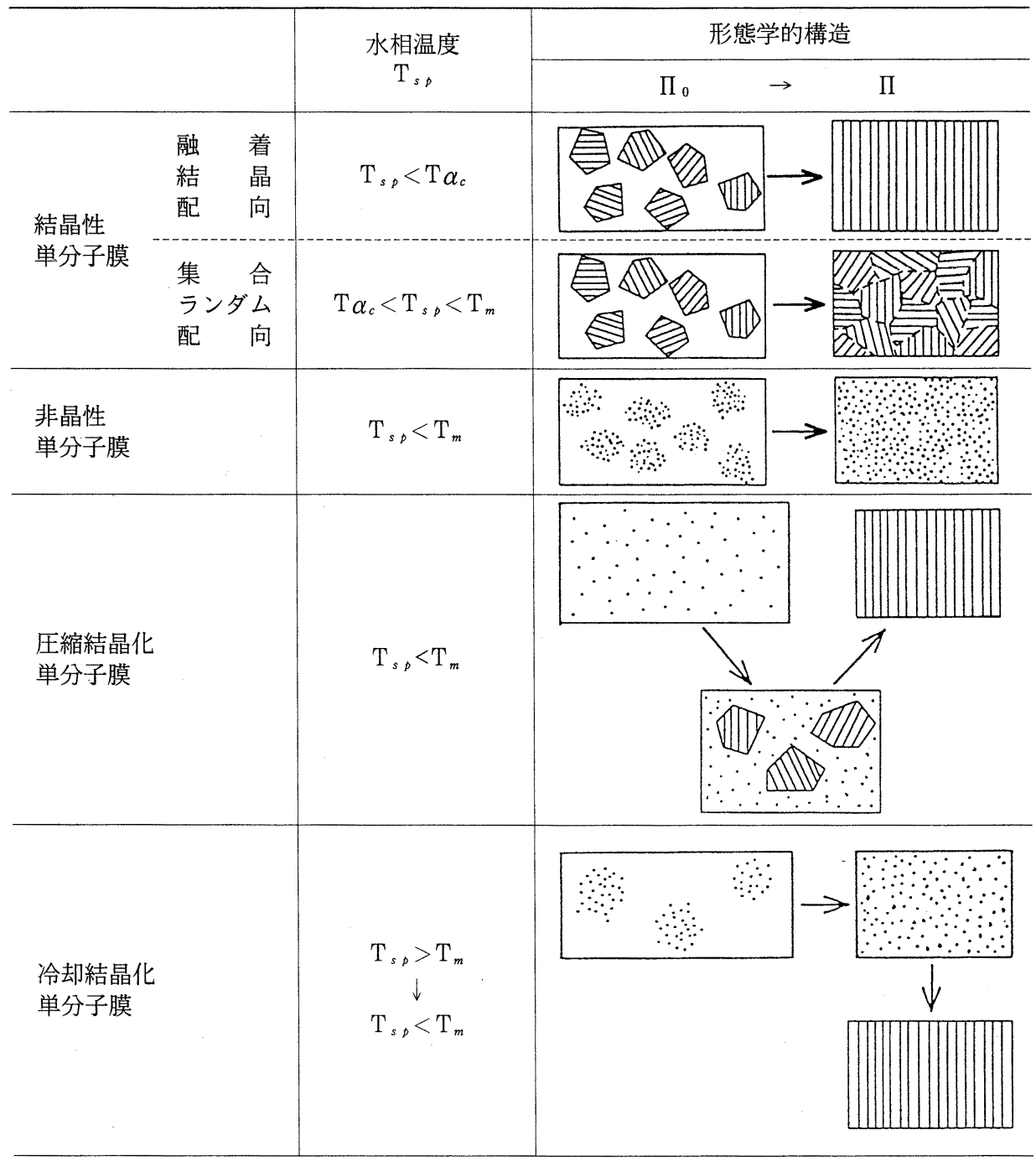

$\mathrm{T}_{s p}:$ 水相温度

$\mathrm{T} \alpha_{c}:$ 結晶緩和温度 $\left(\mathrm{T} \alpha_{c}<\mathrm{T}_{m}\right)$

$\mathrm{T}_{m}:$ 融点

分大きい領域では単分子膜は非晶状態となる. しかし, 非晶状態での圧縮により分子密度が増加するとアルキル 鎖間の凝集力のために結晶化が起こる．プラトー領域は 単分子膜の二次元結晶化が進行し, 結晶相と非晶相の共 存する平衡状態であると考えられる．この様な凝集過程 を示す単分子膜を『圧縮結晶化単分子膜』とよぶ ${ }^{24,25)}$.

以上, 4 節に解説したように, 単分子膜の融点 $\mathrm{T}_{m} \cdot$ 結 晶緩和温度 $\mathrm{T} \alpha_{c}$ と水相温度 $\mathrm{T}_{s p}$ との関係から, 表 1 の ように単分子膜中の分子鎖凝集状態に基づく分類が可能 となる。

\section{5. 新しい単分子膜形成に関する概念}

表 1 に示した単分子膜構造の分類は水面上単分子膜の 分子凝集特性に基づくものであるが，両親媒性分子の熱 力学的特性 $\left(\mathrm{T}_{m}\right.$ と $\left.\mathrm{T} \alpha_{c}\right)$ と化学構造特性（極性基間の 反発）という観点にたてば，水面上単分子膜の凝集構造 は図 10 のように分類できる. 単分子膜形成分子の親水 部がイオン解離していない場合 $\left(\mathrm{T}_{s p}\right.$ と極性基間の反発 力を両軸としたときの第 3,4 象限に相当）には, 試料 溶液が水面上に展開された直後に, 熱拡散により接触し 


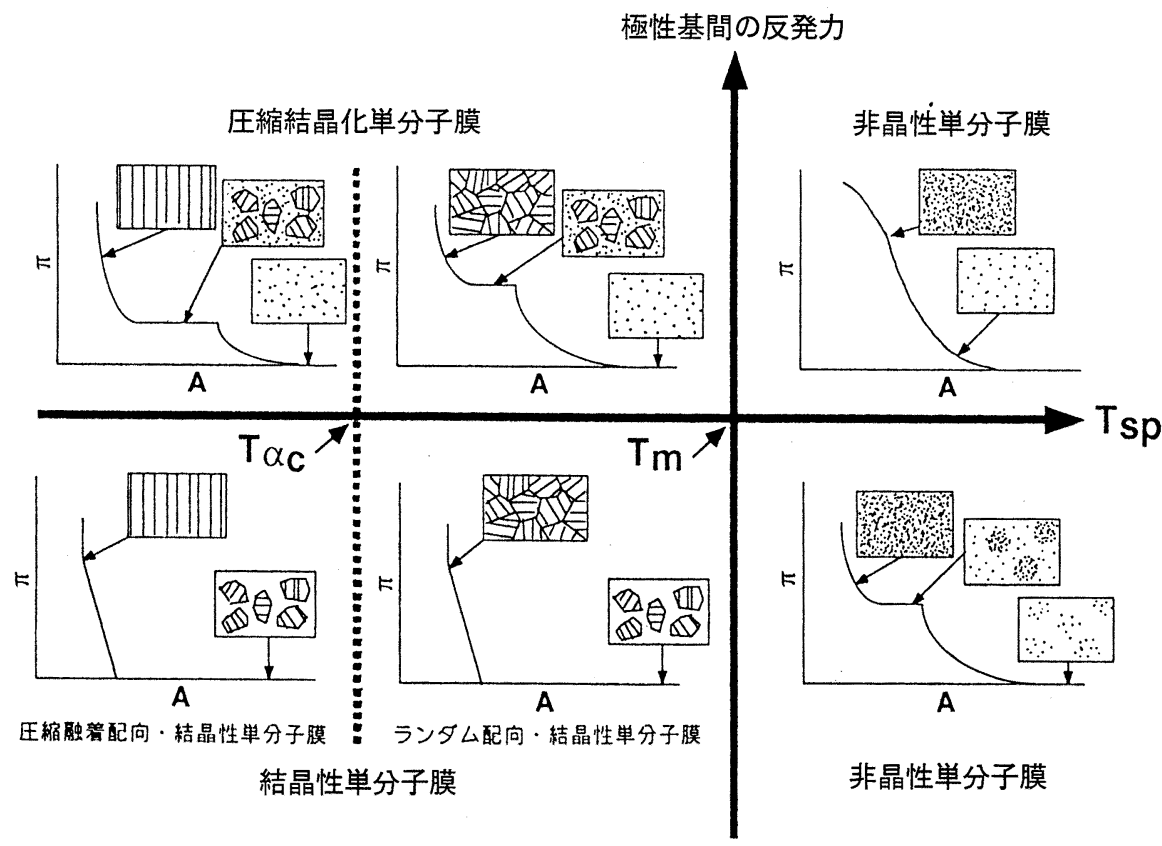

図 10 熱的および化学構造因子に基づく新しい単分子膜の構造モデル

た両親媒性分子同士がファンデルワールスカにより凝集 し，ドメインを形成する．これら単分子膜ドメインは圧 縮操作により寄せ集められ，見かけ上形態学的に均一な 単分子膜を形成する。単分子膜の相状態は， $\mathrm{T}_{s p}$ が単分 子膜の $\mathrm{T}_{m}$ 以下(第 3 象限)であれば結晶相, $\mathrm{T}_{m}$ 以上(第 4 象限)であれば非晶相となり, 各々「結晶性単分子膜」 と「非晶性単分子膜」とに分類される.さらに, 結晶性 単分子膜は $\mathrm{T} \alpha$ ᄃ $\mathrm{T}_{s p}$ との関係より, 圧縮過程で結晶 性ドメインが融着し結晶方位が揃う「圧縮融着配向・結 晶性単分子膜」と結晶性ドメインの結晶方位が揃わない 「ランダム配向・結晶性単分子膜」に分類される. $\mathrm{T}_{m}$ 以 上の $\mathrm{T}_{s p}$ で形成された非晶性ドメインを圧縮しても結 晶化しないのは, 二次元での結晶化表面圧に達する以前 に単分子膜が崩壊するためと考えられる. また, 単分子 膜の崩壊は熱力学的には系外への物質移動を意味するか ら, 単分子膜が熱力学的に閉じた系ではなくなるために, 非晶一結晶相転移が起こらないと換言してもよい，この ことが, 圧縮過程での単分子膜の凝集構造を熱力学的に 閉じた系である気体の圧縮過程と対応づけて議論できな い理由である. しかし, 単分子膜形成分子の親水部がイ オン解離している場合には，例外的に単分子膜の崩壊圧 以下で非晶一結晶相転移が起こる.

単分子膜形成分子の親水基がイオン解離している場合
（第 1,2 象限）には，それら分子は親水基の静電的反発 により低表面圧では凝集できず，水面上に均一に分散し 明確なドメイン構造は形成しない. 単分子膜の $\mathrm{T}_{m}$ 以上 （第 1 象限）では, 分子鎖の熱運動性が高く, 数 $10 \mathrm{mN}$ $\mathrm{m}^{-1}$ の低い表面圧での圧縮でも非晶状態の自由エネル ギーの方が結晶状態のそれより低く非晶一結晶相転移は 生じない. 他方, 単分子膜の $\mathrm{T}_{m}$ 以下（第 2 象限）では, 分子同士が近接すればファンデルワールス相互作用の寄 与により結晶化できる. しかし，低表面圧では極性基の 反発により分子同士が近づけないために単分子膜は非晶 状態である. この非晶状態の単分子膜を圧縮すると分子 同士を近接させることとなり，アルキル鎖の凝集力によ り結晶化が起こる．この凝集特性を示す単分子膜を「圧 縮結晶化単分子膜」とよぶ. なお, 単分子膜の $\mathrm{T}_{m}$ 以上 で親水基が非解離の場合（非晶性単分子膜）と $\mathrm{T}_{m}$ 以下 で親水基がイオン解離している場合（圧縮結晶化単分子 膜）には， $\pi-\mathrm{A}$ 曲線にプラトーが観測される．非解離 系分子の場合はプラトー領域で分子鎖のコンホメーショ ンがゴーシュからトランス化するのに対し, 解離系分子 の場合には，単分子膜の非晶一結晶相転移が生じる.こ れら分子鎖の秩序化と相転移に圧縮エネルギ一が消費さ れるためにプラトーが現われると考えてよい.この事実 は， $\pi-\mathrm{A}$ 曲線のみに基づいて単分子膜の凝集構造を議 
表 2 結溻性および結晶化単分子膜の結晶学的乱れと連続性

\begin{tabular}{lcc}
\hline \multicolumn{1}{c}{ Stearic acid } & $\begin{array}{c}\text { Crystallographical } \\
\text { distortion } \\
(\%)\end{array}$ & $\begin{array}{c}\text { Crystallographical } \\
\text { continuity } \\
(\mathrm{nm})\end{array}$ \\
\hline $\begin{array}{l}\text { Crystalline monolayer } \\
\left(26 \mathrm{mN} \mathrm{m}^{-1}, 293 \mathrm{~K}\right)\end{array}$ & 4.9 & 6.4 \\
$\begin{array}{l}\text { Cooling-crystallized monolayer } \\
\left(15 \mathrm{mN} \mathrm{m}^{-1}, 303 \mathrm{~K}\right)\end{array}$ & 1.5 & $1.2 \times 10^{2}$ \\
\hline
\end{tabular}

論することができないことを示している.

\section{6. 低欠陥単分子膜の構築}

分子流動性が高く, ドメイン界面が存在しないと考え られる非晶性単分子膜を見掛け上, 平衡状態で結晶化す れば（表 1 の冷却結晶化単分子膜），大面積・低欠陥の 単分子膜の構築が可能となる.

ステアリン酸のベンゼン溶液を単分子膜の $\mathrm{T}_{m}=317$ $\mathrm{K}$ 以上の温度である $320 \mathrm{~K}$ に保った純水上に展開し， 非晶性単分子膜を形成させる。これを $15 \mathrm{mN} \mathrm{m}^{-1}$ まで 圧縮し,この表面圧を保ったまま水面上単分子膜の $\mathrm{T}_{m}$ 以下の $\mathrm{T}_{s p}$ まで約 $40 \mathrm{~K} \mathrm{hr}^{-1}$ で冷却後, そのままその 温度で 3 時間保持し, 結晶化させた. その冷却結晶化単 分子膜を表面圧 $26 \mathrm{mN} \mathrm{m}^{-1}$ で基板上に移しとり, 電子 線回折法に基づく single line 法 ${ }^{27)}$ を適用し, 結晶学 的な規則性(乱れ度) と連続性を評価した，表 2 は, 293 $\mathrm{K}, 26 \mathrm{mN} \mathrm{m}^{-1}$ で調製したステアリン酸結晶性単分子 膜と, $303 \mathrm{~K}, 15 \mathrm{mN} \mathrm{m}^{-1}$ で結晶化させたステアリン酸 冷却結晶化単分子膜の, 結晶学的乱れと連続性である. 結晶性単分子膜と比較して, 冷却結晶化単分子膜の方が 結晶学的連続性と結晶相の規則性は著しくよく, 非晶性 单分子膜の冷却結晶化により, 結晶性単分子膜よりもは るかに低欠陥の単分子膜が構築できることが明らかと なった ${ }^{28)}$. 表 2 の冷却結晶化単分子膜の結晶の質に関 する特性はポリエチレン単結晶の場合とほぼ同じであ り, 熱力学的に温和な条件下で調製した高分子単結晶と 同等の結晶状態を有する単分子膜の構築が可能となっ た.

\section{7.おわりに}

単分子膜の静的弾性率の水相温度依存性とその形態構
造論的研究により単分子膜の融点と力学的結晶緩和温度 が評価でき，これらの温度と溶液展開時の水相温度およ び極性基の解離状態に基づき，二次元単分子膜は結晶性 単分子膜, 非晶性単分子膜, 圧縮結晶化単分子膜に大別 できることが明らかとなってきた，LB 膜に整流特性， センサー特性, 導波路特性等の極限機能性を付与するた めには，単分子膜および LB 膜の構造論的, 形態学的, 熱的, 熱機械的（粘弾性）あるいは分光学的解析之検証 および理論的考察等の詳細かつ系統的な研究が必要とな る.

\section{参考文献}

1) Proc. 4 th Int. Conf. on Langmuir-Blodgett Films : in Thin Solid Films, 178-180 (1989).

2) A. Pockels : Nature, 43, 437 (1881).

3) L. Rayleigh : Proc. Roy. Soc., 47, 364 (1890).

4) I. Langmuir : J. Am. Chem. Soc., 39, 1848 (1917).

5) G. L. Gaines : "Insoluble monolayers at Liquid-Gas Interfaces", Interscience, New York (1966).

6) T. Kajiyama, Y. Oishi, M. Uchida, N. Morotomi, J. Ishikawa and Y. Tanimoto : Bull. Chem. Soc. Jpn., 65, 864 (1992).

7) M. Takayanagi, M. Matsuo : J. Macromol. Sci. Phys., B1, 407 (1967).

8) T. Kajiyama, T. Okada, A. Sakoda, M. Takayanagi : J. Macromol. Sci., B7, 583 (1973)

9) T. Kajiyama, T. Okada, M. Takayanagi : J. Macromol. Sci., B9, 35 (1974).

10) M. Takayanagi, T. Aramaki, M. Yoshino, K. Hoashi : J. Polym. Sci., 46, 531 (1960).

11) T. Kijima, K. Koga, K. Imada, M. Takayanagi : Polym. J., 7, 14 (1975).

12) K. Abe, M. Niinomi, M. Takayanagi : J. Macromol. Sci., B7, 583 (1973).

13) K. Iohara, K. Imada, M. Takayanagi, Polym. J., 4, 232 (1973).

14) M. G. Broadhurst: J. Res. Nat. Bur. Stand., 
A70, 481 (1966).

15) T. Kajiyama, I. Hanada, K. Shuto, Y. Oishi : Chem. Lett., 1989, 193.

16) B. Tieke, K. Weiss : J. Colloid Interface Sci., 101, 129 (1984).

17) K. Miyano, A. Mori : Jpn. J. Appl. Phys., 28, 252 (1989).

18) N. Uyeda, T. Takenaka, K. Aoyama, M. Matsumoto, Y. Fujiyoshí : Nature, 327, 319 (1987).

19) T. Kajiyama, K. Umemura, M. Uchida, Y. Oishi, R. Takei : Bull. Chem. Soc. Jpn., 62, 3004 (1989).

20) T. Tanizaki, A. Takahara, T. Kajiyama : J. Soc. Rheol., Jpn., 19, 208 (1991).

21) R. G. Snyder, H. L. Strauss, C. A. Elliger : J. Phys. Chem., 86, 5145 (1982).

22) R.A. MacPhail, R. G. Snyder, H. L. Strauss : J. Chem. Phys., 77, 1118 (1982).
膜 (MEMBRANE), No. 17 Vol. 5 (1992) 343

23) 'T. Kajiyama, Y. Oishi, M. Uchida, Y. Tanimoto, H. Kozuru : Langmuir, 8, 1563 (1992).

24) L. Zhang. M. Uchida, Y. Oishi, A. Takahara, T. Kunitake, T. Kajiyama: Rept. Prog. Polym. Phys. Jpn., 33, 239 (1990) ; T. Kajiyama, L. Zhang, M. Uchida, Y. Oishi, A. Takahara : Langmuir in press.

25) 大石祐司, 小鶴浩之, 梶山千里, 第 44 回コロイド 及び界面化学討論会予稿集, 40 (1990).

26) K. Kjaer, J. A. Nielsen, C. A. Helm, L. A. Laxhuber, H. Möhwold : Phys. Rev. Lett., 58, 2224 (1987).

27) D. Hofmann, E. Walenta : Polymer, 28, 1278 (1978).

28) T. Kajiyama, K. Umemura, M. Uchida, Y. Tanimoto, R. Takei : Chem. Lett., 1989, 1515.

（受付 1992 年 6 月 15 日） 